\title{
Osmotic dehydration kinetics of oyster mushroom
}

\author{
S. Yasmin ${ }^{1}$, M. N. Islam ${ }^{2}$, M. A. Alim ${ }^{2}$ and M. S. Kamal ${ }^{2}$ \\ ${ }^{1}$ Department of Food Engineering and Technology, Hajee Mohammad Danesh Science and Technology University, Dinajpur \\ ${ }^{1,2}$ Department of Food Technology and Rural Industries, Bangladesh Agricultural University, Mymensingh-2202, Bangladesh

\begin{tabular}{|c|c|}
\hline ARTICLE INFO & Abstract \\
\hline $\begin{array}{l}\text { Article history: } \\
\text { Received: } 22 \text { August } 2017 \\
\text { Accepted: } 30 \text { November } 2017\end{array}$ & \multirow{3}{*}{$\begin{array}{l}\text { This research was carried out to study the effect of osmotic dehydration behavior of oyster mushroom. } \\
\text { The effect of solution concentration, immersion time and temperature on mass transfer parameters were } \\
\text { observed during osmotic dehydration of oyster mushroom at three different temperatures }-12,27 \text { and } \\
45^{\circ} \mathrm{C} \text {. A number of process parameters on osmotic dehydration such as water loss (WL), solid gain (SG), } \\
\text { and normalized solid content (NSC) were investigated. Results showed that increase in salt concentration } \\
\text { and immersion time resulted in \%WL, } \% \mathrm{SG} \text { and NSC. The highest NSC ( } 4.09 \mathrm{~g} \text { solids } / 100 \mathrm{~g} \text { of initial } \\
\text { weight of sample) was achieved for product osmosed in } 25 \% \text { salt solution for } 6 \mathrm{hr} \text { immersion time. The } \\
\text { pseudo diffusion coefficient, k was determined by using Fick's First Law of diffusion equation. Plotting k } \\
\text { values against inverse absolute temperature an Arrhenius type relationship was developed from which the } \\
\text { calculated activation energy values of } 1.8 \text { and } 3.64 \mathrm{kcal} / \mathrm{gm} \text {-mole were obtained for } 20 \% \text { and } 15 \% \text { salt } \\
\text { solution respectively. }\end{array}$} \\
\hline $\begin{array}{l}\text { Keywords: } \\
\text { Oyster mushroom, Osmotic } \\
\text { dehydration, Water loss, Solid } \\
\text { Gain, Normalized Solid Content }\end{array}$ & \\
\hline $\begin{array}{l}\text { Correspondence: } \\
\text { S. Yasmin } \\
\text { (sabina.fpe@gmail.com) }\end{array}$ & \\
\hline
\end{tabular}

\section{Introduction}

A special group of macroscopic fungi, known as mushrooms lack in chlorophyll and hence require a substrate for their own absorptive nutrition. Enzymes producing fungi degrade complex organic matter and absorb the soluble substances (Chang and Miles, 1989). Mushroom is a soft delicate white fruit-body of the fleshy fungi. The microscopic fine thread-like body called mycelium is the real fungus which grows on the substratum or under the surface of soil. When matured, the mycelia come together in a very compact form and sprout and spread as umbrella like structure (Chung et al., 1981). Mushrooms have been evaluated as sources of dietary nutrients and pharmacologically vital compounds beneficial for medicine since times immemorial. They are considered to be a source of many different nutraceuticals such as unsaturated fatty acids, phenolic compounds, tocopherols, ascorbic acid and carotenoids. Thus, they are used directly in diet to promote health, taking advantage of the additive and synergistic effects of all the bioactive compounds present (Pereira et al., 2012; Vaz et al., 2010).

Mushrooms of Pleurotus sp. are commonly called 'Oyster mushrooms'. They are the second most popular mushrooms after button mushroom throughout the world (Adejoye et al., 2006) and the most popular in Bangladesh. The production of four species of oyster mushroom: Pleurotus ostreatus, P. florida, P. sajor-caju and $P$. high king cultivated in every season (January to December) in Bangladesh(Uddin M. N. et al.,2011).Nowadays mushrooms are becoming a popular food in daily meal because of their nutritious and medicinal values. Edible mushrooms are rich in protein, and are excellent source of fibers, vitamins and minerals (Manjunathan et al., 2011). In general, the fruiting bodies of mushrooms contain about $56.8 \%$ carbohydrate, $25.0 \%$ protein, $5.7 \%$ fat and $12.5 \%$ ash on a dry weight basis (Ouzouni et al., 2009).

Edible mushroom in fresh, cooked or processed forms are nutritionally sound, tasteful food source for most people and can be a significant dietary component for vegetarians. The nutritional value of edible mushrooms compares favorably to that of most vegetables.

Fruits and vegetables are perishable due to their high moisture content. Osmotic dehydration (OD) as a predrying treatment has received considerable attention in recent years, as it reduces energy consumption, improves food quality, and reduces the drying time. The technique consists of immersing fruit/vegetables in a hypertonic solution to concentrate vegetables or fruits. Sereno et al. (2001) stated that osmotic dehydration is a useful technique that involves product immersion in a hypertonic aqueous solution leading to loss of water through the cell membranes of the product and subsequent flow along the inter-cellular space before diffusing into the solution.

The osmotic process is a method of partial removal of water from product by immersing it in a hypertonic solution. The process is facilitated by the osmotic pressure difference between the food material (hypotonic medium) and concentrated osmotic solution (hypertonic medium). As osmotic dehydration does not give a product of low moisture content considered for shelf stable therefore osmosed products are needed 
further dried up to desired moisture content, in association with other methods of food preservation including freezing, vacuum dehydration and oven or freeze drying (Torringa et al., 2001).Osmotic dehydration makes significant changes in the final dehydrated product such as volume reduction, membrane alteration and membrane separation from the cell wall. It also increases nutritional, sensorial and functional properties of food without changing its integrity (Torrengiani, 1993).

Osmotic dehydration is a process through which water is removed from the cell membrane and solid uptake. Time, temperature, solution concentration and also other parameters has a notable effect on osmosis. Therefore, current research was designed with the following objectives:

i) To determine the osmotic drying behavior of oyster mushroom.

ii) To assess the effect of different parameter (time, temperature, solution concentration etc) on osmosed mushroom.

iii) To investigate the mass transfer actions of osmosed mushroom.

\section{Materials and Methods}

The experiment was conducted in the laboratory of the Department of Food Technology and Rural Industries, Faculty of Agricultural Engineering and Technology, Bangladesh Agricultural University, Mymensingh during October 2012- April, 2013.

\section{Sample preparation}

Fresh oyster mushrooms were collected from Horticulture Centre, Keawatkhali, Mymensingh. Five different salt concentrations (i.e. 5\%, 10\%, 15\%, 20\% and $25 \%$ ) were made using salt and distilled water. Salt was used for retarding oxidative non-enzymatic browning (Kumar et al., 2009).

Other materials such as drying tray, polythene bags and distilled water were provided by the laboratory of the Department of Food Technology and Rural Industries.

\section{Osmotic dehydration treatment}

Fresh mushroom were collected and initial moisture content was determined by oven drying method (AOAC 2005). Appoximately 100gm of mushrooms were immersed into $5 \%, 10 \%, 15 \%, 20 \%$ and $25 \%$ salt solution using a solution to product ratio of $6: 1$ at different temperatures $\left(12,27\right.$ and $\left.45^{\circ} \mathrm{C}\right)$ for $30 \mathrm{~min}$, $1 \mathrm{hr}, 2 \mathrm{hr}, 3 \mathrm{hr}, 4 \mathrm{hr}$ and upto $6 \mathrm{hr}$. At the end of each definite time interval samples were removed and boltted gently with tissue-paper. The osmosed mushroom was then weighted and moisture content of each individual sample was determined. Percentage of water loss $(\% \mathrm{WL})$, solid gain $(\% \mathrm{SG})$, total solid (TS), and normalised solid content (NSC) were determined according to Hawkes and Flink (1978) with the following equations:

Water loss \% WL $(\mathrm{wb})=$ $\frac{\text { WWO }-(\mathrm{TW}-\mathrm{WS})}{\mathrm{WSO}+\mathrm{WWO}} \times 100, \mathrm{~g}$ solids $/ 100 \mathrm{~g}$ initial wt. of sample

Solid Gain \% SG (wb) =

$\frac{\text { WS }- \text { WSO }}{\text { WSO }+ \text { WWO }} \times 100, \mathrm{~g} \frac{\text { solids }}{100 \mathrm{~g}}$ initial wt. of sample

Total solid, $\% \mathrm{TS}=\frac{\mathrm{WS}}{\mathrm{TW}} \times 100 \mathrm{~g} \frac{\text { solids }}{100 \mathrm{~g}}$ of initial weight of sample

Normalized Solid Content $=\frac{\text { Total solids at any time }}{\text { Initial solids content }}$

Where, TW = total weight of the sample upon removal from the osmosis solution ,WS = total weight of solid content of the sample determined after removal from the osmosis solution, WSO = solid content of the initial sample, $\mathrm{WWO}=$ water content of the initial sample.

\section{Statistical Analysis}

The experimental data were evaluated by analysis of variance (ANOVA) and means were compared at a significance level of 5\%, by using Statistical Package for Social Science (SPSS $16^{\text {th }}$ version).

\section{Results and Discussion}

Effect of solution concentration and temperature on normalized solid content (NSC)

Solution concentration has a more noticeable effect on Normalised Solid Content (NSC). For the investigation of the effect of solution concentration on NSC, experiments were conducted with $5 \%, 10 \%, 15 \%, 20 \%$ and $25 \%$ salt solution for a period of $6 \mathrm{hrs}$. 


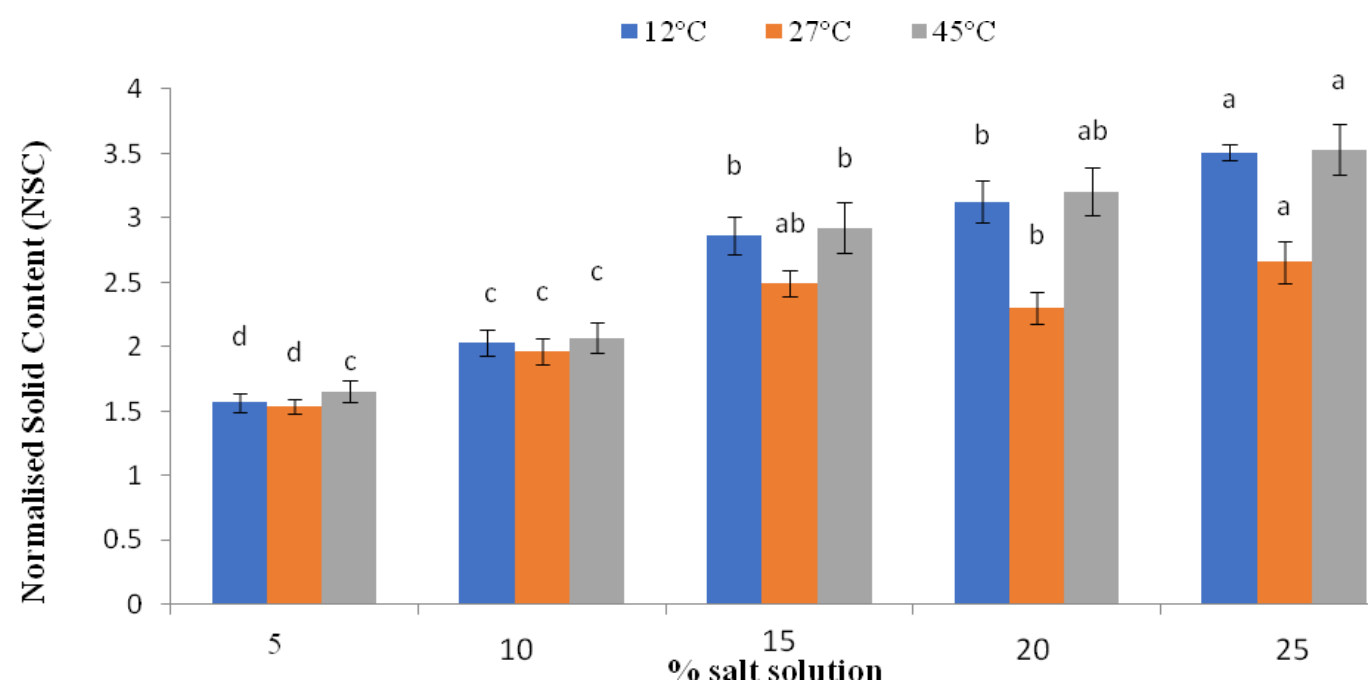

Fig. 1. Effect of solution concentration on NSC of osmosed mushroom at three different temperature $\left(12,27,45^{\circ} \mathrm{C}\right)$ with error bar representing standard error of mean at $95 \%$ confidence level. $\left[{ }^{* a-d}\right.$ means followed by different subscript alphabets in each temperature are significantly different $(\mathrm{p}<0.05)$ among different normalised solid content]

From the above Fig. 1 it is seen that at a given time increase in salt concentration gave increased NSC. In $5 \%$ and $10 \%$ salt solution NSC content are statistically different from $15 \%$ to $25 \%$ salt solution because no overlap is occured among the error bar.

Mushroom osmosed in 25\% salt solution for $6 \mathrm{hr}$ give significantly higher NSC than the other sample osmosed at $20 \%, 15 \%, 10 \%$ and $5 \%$ at $(\mathrm{P}<0.05)$. Mushroom osmosed in $25 \%$ salt solution for $6 \mathrm{hr}$ provides significantly higher NSC (3.53) at $45^{\circ} \mathrm{C}$ followed by NSC 3.51 at $12^{\circ} \mathrm{C}$ and $2.66 \mathrm{NSC}$ at $27^{\circ} \mathrm{C}$, while at $5 \%$ salt solution significantly lower NSC (1.54) was found at $27^{\circ} \mathrm{C}$ followed by $1.65 \mathrm{NSC}$ at $45^{\circ} \mathrm{C}$ and $1.57 \mathrm{NSC}$ at $12^{\circ} \mathrm{C}$.

Hawkes and Flink 1978, Islam 1980 observed that, the higher NSC with increased solution concentration at a given immersion of time is due to higher activity gradient. The increased NSC at a given solution concentration and time with increased solution temperature up-to $27^{\circ} \mathrm{C}$ is due the fact that NSC is related to $V_{t}$ by pseudo diffusion co efficient (Hawkes and Flink, 1978) which is related to temperature by and Arrhenius type equation (Singh and Heldmen, 2008).

\section{Effect of solution concentration and immersion time} on percent water loss and percent solid gain

To determine the effects of osmosis solution concentration and immersion time five different salt solution $(5,10,15,20$ and $25 \%)$ were used as osmosis solution in which samples were immersed for different period of time up-to $6 \mathrm{hrs}$. and percent water loss (\%WL) and percent solid gain (\%SG) were determined. Osmosis solution temperatures were maintained at $12^{\circ} \mathrm{C}$, $27^{\circ} \mathrm{C}$ and $45^{\circ} \mathrm{C}$. The results are shown in Table 1 and Table 2.

From Table 1 and 2, it is observe that, water loss (\%) and solid gain (\%) are significantly different at different immersion time as well as in most of the cases they are also significantly different from each other at a same time in changed temperature. At the same time, water loss (\%) and solid gain (\%) are significantly different at different solution concentration also at constant concentration in different temperature (Table-2).

In general the results show that, as time of immersion increases water loss (\%WL) increases for a given solution concentration and so is solid gain (\% SG) but the water loss (\%WL) is always significantly higher than solid gain (\%SG). Similarly, for constant immersion time $(6 \mathrm{hr})$ water loss (\%) rises with increasing concentration of salt in solution up to $25 \%$ salt (48.33 $\% \mathrm{WL}$ at $45^{\circ} \mathrm{C}$ and $42.75 \% \mathrm{WL}$ at $27^{\circ} \mathrm{C}$ ) and thereafter at $20 \%$ salt solution slightly decrease in $\% \mathrm{WL}$ is observed $\left(37.13 \%\right.$ at $27^{\circ} \mathrm{C}$ and 45.53 at $\left.45^{\circ} \mathrm{C}\right)$.

It is also seen that at constant immersion time $(6 \mathrm{hr})$, solid gain is increases with increasing osmosis solution concentration and $25 \%$ salt solution gives high \%SG such as $13.02 \% \mathrm{SG}$ at $27^{\circ} \mathrm{C}$, while at $45^{\circ} \mathrm{C} \% \mathrm{SG}$ is as 10.79. The results also show that in general, for constant solution concentration and time as temperature is increased \%WL and \%SG increased with an exception in each case.

The observed behaviour of immersion time on \% WL and \% SG has been previously reported by Islam and Flink (1982) and Hawkes and Flink (1978). Iqbal and Islam (2005) while studying osmotic concentration behavior of cauliflower and cucumber in 5 to $15 \%$ salt solution observed that at constant solution concentration, increased time gives increased $\% \mathrm{WL}$ and $\% \mathrm{SG}$.

Finally it is observed that 20 and $25 \%$ salt solution was more effective than other solutions at the same immersion time. 
Table 1. Effect of immersion time on water loss (\%) and solid gain (\%) of osmosed mushroom

\begin{tabular}{c|cccc|cc}
\hline Immersion & \multicolumn{2}{|c|}{$12^{\circ} \mathrm{C}$ temperature } & \multicolumn{2}{c|}{$27^{\circ} \mathrm{C}$ temperature } & \multicolumn{2}{c}{$45^{\circ} \mathrm{C}$ temperature } \\
\cline { 2 - 7 } time (hr.) & Water loss $(\%)$ & Solid gain (\%) & Water loss (\%) & Solid gain (\%) & Water loss $(\%)$ & Solid gain $(\%)$ \\
\hline 0.5 & $25.16 \pm 14.46^{\mathrm{b}}$ & $7.03 \pm 3.64^{\mathrm{a}}$ & $22.21 \pm 8.37^{\mathrm{d}}$ & $5.30 \pm 3.13^{\mathrm{b}}$ & $29.25 \pm 10.68^{\mathrm{d}}$ & $4.84 \pm 3.04^{\mathrm{b}}$ \\
1 & $32.26 \pm 14.65^{\mathrm{ab}}$ & $7.33 \pm 3.72^{\mathrm{a}}$ & $25.96 \pm 7.42^{\mathrm{cd}}$ & $6.08 \pm 3.25^{\mathrm{b}}$ & $33.31 \pm 9.11^{\mathrm{cd}}$ & $5.82 \pm 3.02^{\mathrm{ab}}$ \\
2 & $33.76 \pm 11.59^{\mathrm{ab}}$ & $8.54 \pm 4.70^{\mathrm{a}}$ & $31.16 \pm 8.85^{\mathrm{bc}}$ & $6.59 \pm 3.15^{\mathrm{ab}}$ & $36.67 \pm 7.89^{\mathrm{bcd}}$ & $6.54 \pm 3.01^{\mathrm{ab}}$ \\
3 & $37.65 \pm 11.01^{\mathrm{a}}$ & $9.02 \pm 4.62^{\mathrm{a}}$ & $34.75 \pm 9.02^{\mathrm{ab}}$ & $7.31 \pm 3.06^{\mathrm{ab}}$ & $42.63 \pm 11.65^{\mathrm{abc}}$ & $7.24 \pm 3.23^{\mathrm{ab}}$ \\
4 & $39.30 \pm 10.29^{\mathrm{a}}$ & $9.20 \pm 4.93^{\mathrm{a}}$ & $37.13 \pm 9.32^{\mathrm{ab}}$ & $7.89 \pm 3.11^{\mathrm{ab}}$ & $45.53 \pm 12.26^{\mathrm{ab}}$ & $7.92 \pm 3.24^{\mathrm{ab}}$ \\
6 & $40.78 \pm 10.10^{\mathrm{a}}$ & $9.57 \pm 4.96^{\mathrm{a}}$ & $42.75 \pm 9.243^{\mathrm{a}}$ & $9.96 \pm 5.50^{\mathrm{a}}$ & $48.33 \pm 12.25^{\mathrm{a}}$ & $8.88 \pm 3.25^{\mathrm{a}}$ \\
\hline
\end{tabular}

*a-d Means followed by different subscript alphabets in each column are significantly different $(\mathrm{P}<0.05)$ among different immersion time. * Mean \pm standard deviation

Table 2. Effect of solution concentration on water loss (\%) and solid gain (\%) of osmosed mushroom

\begin{tabular}{c|cc|c|c|cc}
\hline $\begin{array}{c}\text { Concentration } \\
(\%)\end{array}$ & \multicolumn{2}{|c|}{$12^{\circ} \mathrm{C}$ temperature } & \multicolumn{2}{|c|}{$27^{\circ} \mathrm{C}$ temperature } & \multicolumn{2}{|c}{$45^{\circ} \mathrm{C}$ temperature } \\
\cline { 2 - 7 } & $\begin{array}{c}\text { Water loss } \\
(\%)\end{array}$ & $\begin{array}{c}\text { Solid gain } \\
(\%)\end{array}$ & $\begin{array}{c}\text { Water loss } \\
(\%)\end{array}$ & $\begin{array}{c}\text { Solid gain } \\
(\%)\end{array}$ & $\begin{array}{c}\text { Water loss } \\
(\%)\end{array}$ & $\begin{array}{c}\text { Solid gain } \\
(\%)\end{array}$ \\
\hline 5 & $22.70 \pm 4.55^{\mathrm{b}}$ & $2.72 \pm .99^{\mathrm{e}}$ & $21.63 \pm 5.13^{\mathrm{c}}$ & $3.61 \pm .90^{\mathrm{d}}$ & $23.01 \pm 5.81^{\mathrm{c}}$ & $3.71 \pm 1.07^{\mathrm{d}}$ \\
10 & $27.25 \pm 9.47^{\mathrm{b}}$ & $6.15 \pm .68^{\mathrm{d}}$ & $26.29 \pm 7.90^{\mathrm{c}}$ & $5.70 \pm 2.04^{\mathrm{c}}$ & $35.28 \pm 8.29^{\mathrm{b}}$ & $4.04 \pm 1.55^{\mathrm{d}}$ \\
15 & $27.61 \pm 7.05^{\mathrm{b}}$ & $14.80 \pm 2.86^{\mathrm{a}}$ & $43.44 \pm 5.87^{\mathrm{a}}$ & $5.78 \pm 2.11^{\mathrm{c}}$ & $42.28 \pm 9.21^{\mathrm{a}}$ & $6.62 \pm 2.75^{\mathrm{c}}$ \\
20 & $46.36 \pm 5.27^{\mathrm{a}}$ & $7.79 \pm .68^{\mathrm{c}}$ & $35.97 \pm 9.48^{\mathrm{b}}$ & $7.82 \pm .98^{\mathrm{b}}$ & $47.62 \pm 10.07^{\mathrm{a}}$ & $9.21 \pm 1.36^{\mathrm{b}}$ \\
25 & $50.16 \pm 2.54^{\mathrm{a}}$ & $10.78 \pm .83^{\mathrm{b}}$ & $34.30 \pm 9.95^{\mathrm{b}}$ & $13.02 \pm 3.29^{\mathrm{a}}$ & $48.25 \pm 7.09^{\mathrm{a}}$ & $10.79 \pm 1.56^{\mathrm{a}}$ \\
\hline
\end{tabular}

*a-e Means followed by different subscript alphabets in each column are significantly different $(\mathrm{P}<0.05)$ among different $\quad$ solution concentration. * Mean \pm standard deviation

Effect of temperature on percent water loss and percent solid gain of osmosed mushroom

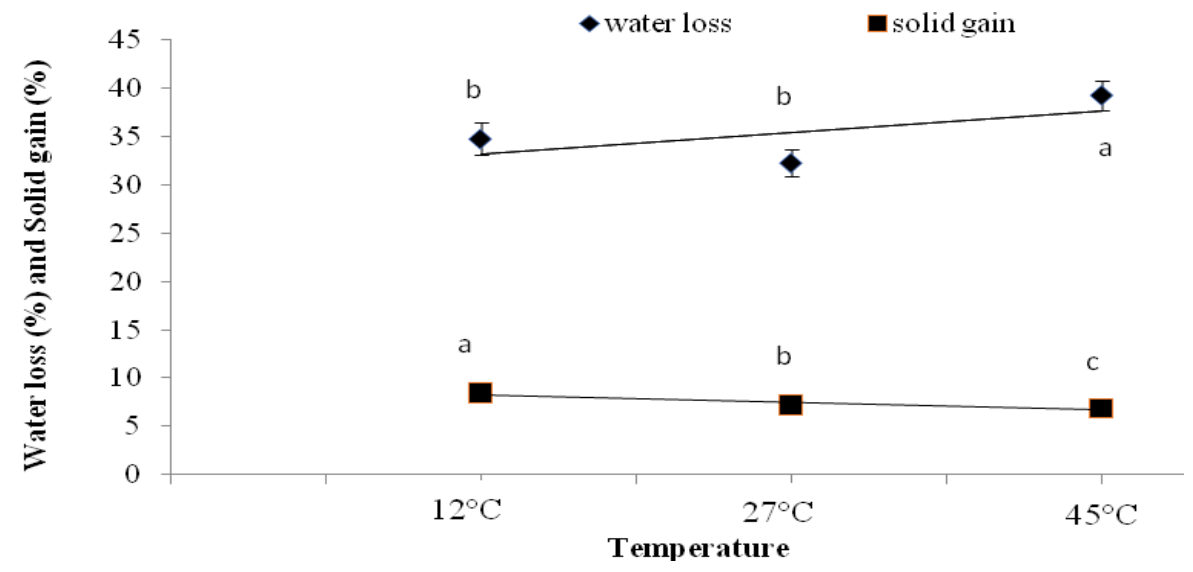

Fig. 2. Effect of temperature on water loss (\%) and solid gain (\%) of osmosed mushroom with error bar representing standard error of mean at $95 \%$ confidence interval.

From the examination of Fig. 2 it is reveals that increasing temperature gave increasing water loss $(\%)$ but solid gain decrease with increasing temperature. During osmotic treatment, when temperature increased then water loss and solid gain took place (Alakali et al, 2006, Rafiq Khan, 2012). Beristain et al. (1990) stated that increase in temperature of osmotic solution results in increases in water loss, whereas solid gain is less affected by temperature (Tortoe, 2010).

Rahman and Lamb (1990) also observed that at high temperature solute does not diffuse as easily as water through the cell membrane and thus the approach to osmotic equilibrium is achieved primarily by flow of water from the cell resulting in a lower solute gain by the food material.

\section{Kinetics of osmotic dehydration}

The most important variable affecting the kinetics of mass transfer during osmotic dehydration is temperature
(Tortoe, 2010). At constant salt solution concentration, increase in immersion time gave increased normalized solid content. In order to analyze osmotic dehydration kinetics as per Fick's First Law (Hawkes and Flink, 1978) equation NSC values for $15 \%$ and $20 \%$, of salt solution were plotted vs square root of time $(\sqrt{ } \mathrm{t})$ (representative figure 3) for mushroom and a linear relationship is obtained as:

For $15 \%$ salt solution

$\mathrm{NSC}=0.657 \sqrt{\mathrm{t}}+1.767 \ldots \ldots$ at $12^{\circ} \mathrm{C}$

$\mathrm{NSC}=0.634 \sqrt{\mathrm{t}}+1.514 \ldots \ldots$ at $27^{\circ} \mathrm{C}$

$\mathrm{NSC}=1.242 \sqrt{\mathrm{t}}+1.002 \ldots \ldots$ at $45^{\circ} \mathrm{C}$

For $20 \%$ salt solution

$\mathrm{NSC}=0.352 \sqrt{\mathrm{t}}+2.392 \ldots \ldots$ at $12^{\circ} \mathrm{C}$

$\mathrm{NSC}=0.5 \sqrt{\mathrm{t}}+1.610 \ldots \ldots \ldots$ at $27^{\circ} \mathrm{C}$

$\mathrm{NSC}=0.489 \sqrt{\mathrm{t}}+1.978 \ldots$. . at $45^{\circ} \mathrm{C}$ 




Fig. 3. Effect of square root of time on NSC for $15 \%$ and $20 \%$ salt solution at different temperature

From the above regression equations and representative Fig. 3 it was seen that the mass transfer co-efficient (k-value) at $15 \%$ salt solution for $6 \mathrm{hr}$ osmosis were $0.657,0.634$, and 1.242 at 12,27 and $45^{\circ} \mathrm{C}$, respectively and observed that $\mathrm{k}$ value is quite higher at $45^{\circ} \mathrm{C}$. Again for $20 \%$ salt solution the corresponding $\mathrm{k}$ values are $0.352,0.5$, and 0.489 , respectively and slightly lower $\mathrm{k}$-value is found for $45^{\circ} \mathrm{C}$ compared to $27^{\circ} \mathrm{C}$. The fluctuating mass transfer coefficient, $\mathrm{k}$ value for osmotic dehydration of oyster mushroom may be due to its sensitiveness to temperature which might have destroyed the effectiveness of cellular membrane. Islam (1980) and Pader and Richberg (1968) also showed that high temperature had adverse effect on osmotic dehydration.
Relationship between mass transfer coefficient ( $\mathrm{k}$ value) and inverse absolute temperature is generally described by Arrhenius type relationship reported as by Brooker et al. (1974) and Singh and Heldmen (2008). The determined $\mathrm{k}$-value for osmosed mushroom was plotted against inverse absolute temperature on semi-log coordinate (figures $4 \mathrm{a}$ and $4 \mathrm{~b}$ ) to describe the influence of temperature on osmotic concentration behavior. By regression analysis the following equations were developed:

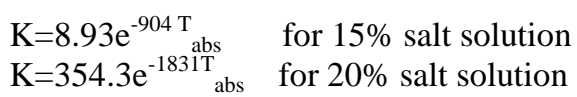

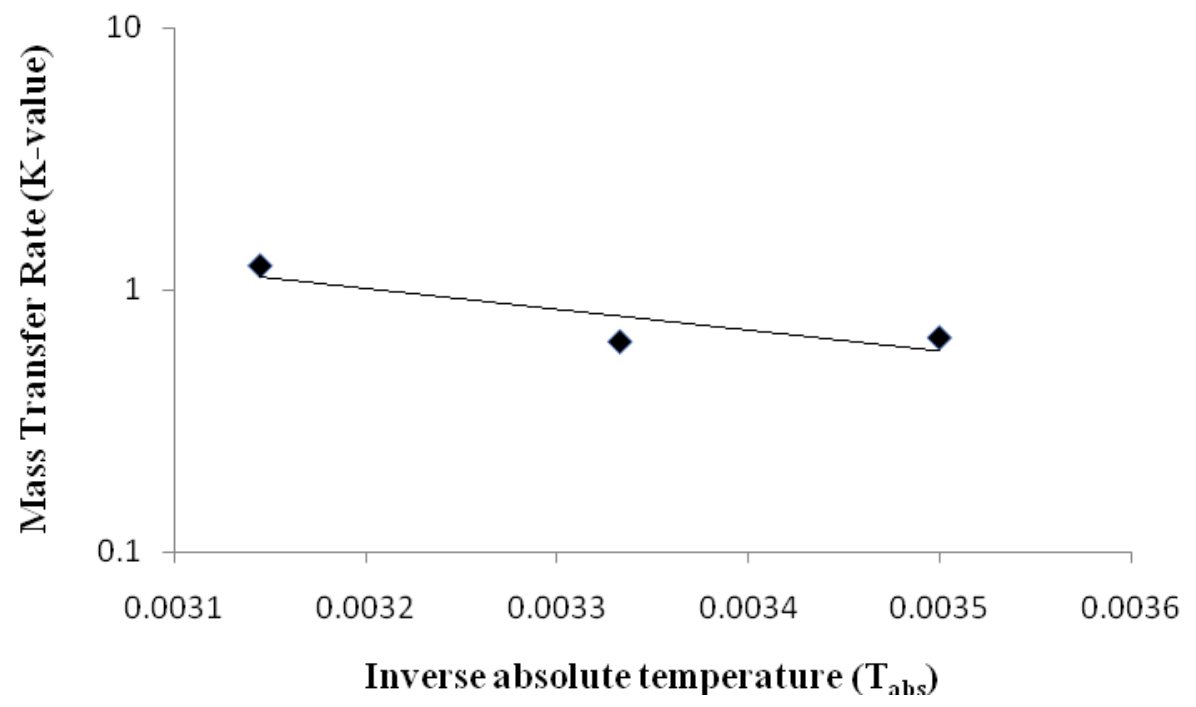

Fig. 4(a). Effect of temperature on mass transfer rate of mushroom at $15 \%$ salt solution 


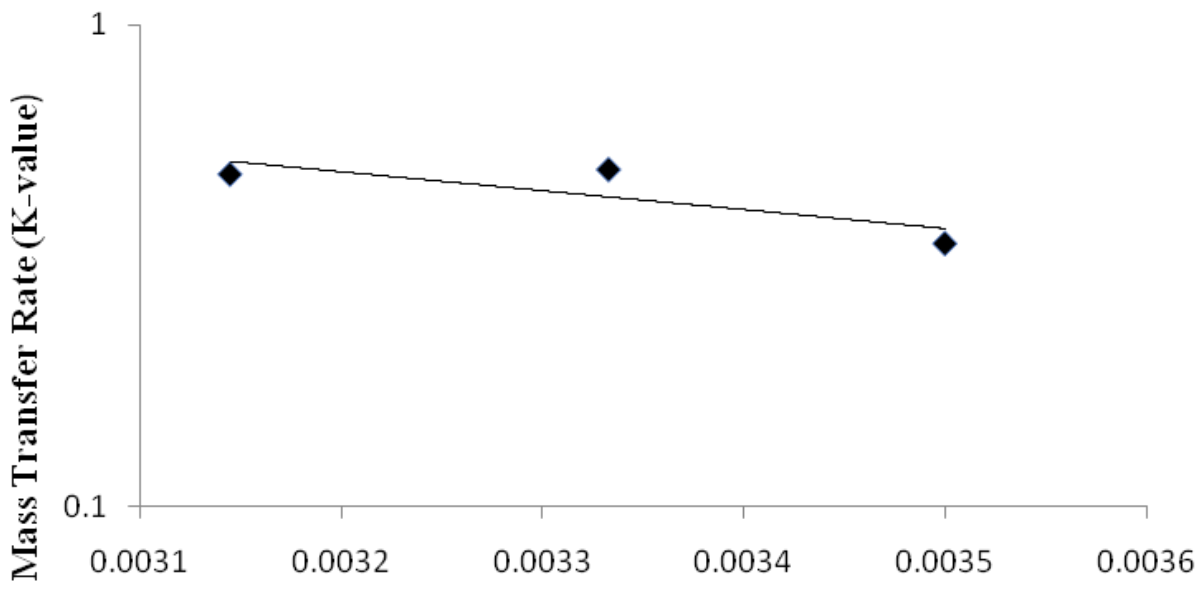

Inverse absolute temperature $\left(\mathrm{T}_{\mathrm{ahs}}\right)$

Fig. 4(b). Effect of temperature on mass transfer rate of mushroom at $20 \%$ salt solution.

From the equations, the activation energy is calculated as $1.796 \mathrm{kcal} / \mathrm{g}$-mole for $20 \%$ salt solution and 3.64 $\mathrm{kcal} / \mathrm{g}-\mathrm{mole}$ for $15 \%$ salt solution. The values are much lower than the activation energy of sweet potato (12 $\mathrm{kcal} / \mathrm{g}$-mole) reported by Islam and Cowell (1989) but closer to those reported by Iqbal and Islam (2005) who found for cauliflower and cucumber 1.3 and $4.18 \mathrm{kcal} / \mathrm{g}$ mole activation energy value respectively.

\section{Summary and conclusion}

Results showed that solution concentration and temperature of osmotic solution had a significant role in increasing water loss and solid gain. Statistical results revels that moisture content deduce with increasing solid gain. Mass transfer co-efficient for various solution concentrations were calculated according to Fick's first law of diffusion. Activation energy was also observed.

Therefore, osmotic dehydration was found to be as an effective pretreatment method for reducing the moisture content for further drying.

\section{Acknowledgements}

The authors are grateful to National Science and Technology (NST) authority as the research was supported by a research fellowship from NST (National Science and Technology), Ministry of Science and Technology, Government of the People's Republic of Bangladesh.

\section{References}

Adejoye, O.D., Adebayo, T, Ogunjobi, A.A., Olaoye, O.A. and Fadahunsi, F.I. 2006. Effect of carbon, nitrogen and mineral sources on growth of Pleurotus florida, a Nigeria edible mushroom. African J. Biotechnology. 5: 1355-1359.

Alakali JS, Ariahu CC, kpa NNN. 2006. Kinetics of osmotic dehydration of mango, Journal of Food Processing and Preserv., 30: 597-607.
AOAC, 2005. Official Methods of Analysis of the Association of official Analytical Chemist. $19^{\text {th }}$ Ed. Washington D.C

Beristain CL, Azuara E, Cortes R, Garcia HS1990. Mass transfer during osmotic dehydration of pineapple rings. Int. J. Food Sci. Technol., 25: 576-582

Brooker, D.B., Bakker, A.F.W. and Hall, C.W.1974. Drying Cereal Grains. $1^{\text {st }}$ Edition. The AVI Publishing Company Inc.West Port, Connecticut.

Chang, S. T. and P. G. Miles. 1989. Edible mushrooms and their cultivation. CRC Press, Inc. Florida, 345p.

Chung,H.C., Y.H. Park and Y.S. Kim, 1981. Basic Information on the Characteristics of Strains of Oyster Mushroom. Korean J. Mycol., 9: 129-132.

Hawkes, J. and Flink, J.M., 1978. Osmotic concentration of fruit slice prior to freeze dehydration. J. Food Proc. Preserv. 2: 265284.

Iqbal, A. and Islam, M.N., 2005. Dehydration kinetics of cauliflower and cucumber. Bangladesh J. Agril. Engg. 16 (1): 113-122

Islam, M. N. 1980. Use of solar energy for development of shelf-stable potato product. Ph.D. Thesis, Royal Veterinary and Agriculture University, Copenhagen, Denmark.

Islam, M.N. and Cowell, N.D., 1989. The kinetics of water loss in the osmotic dehydration of sweet potato. Bangladesh J. Agril. Engg. Vol.3: No.1\& 2

Islam, M.N. and Flink, J.M. 1982. Analysis of drying behaviour of fresh and osmotically dehydrated potato. Chem. Engg. Research Bulletin, 6: 38. J. of Food Sci., 22(2): 71-85.

Kumar, V., G., Kumar, and P. D., Sharma. 2009. Effect of osmoconvective drying on quality of Litchi. J. of Agril Enng, 46(4): $31-35$

Manjunathan,J. and Kaviyarasan, V., 2011. Nutrient composition in wild and cultivated edible mushroom, Lentinus tuberregium (Fr.) Tamil Nadu., India. Int. Food Research Journal 18: 784-786

Ouzouni, P.K., Petridis, D., Koller, W.D., and Riganakos, K.A., 2009. Nutritional value and metal content of wild edible mushrooms collected from West Macedonia and Epirus, Greece. Food Chem., 115: 1575-1580.

Pader, M. and Richberg, C.G., 1968. Process for preparing dehydrated fruits. U.S patent 3,565,309. 
Pereira, E., Barros, L., Martins, A. and Ferreira, I.C.F.R. 2012. Towards chemical and nutritional inventory of Portuguese wild edible mushrooms in different habitats. Food Chem., 130: 394-403.

R. paul singh and Dennis R. Heldman.2008. Introduction to Food Engineering, Fourth edition. Academic Press is an imprint of Elsevier.

Rafiq Khan M. 2012. Osmotic dehydration technique for fruits preservation-A review, Pakistan

Rahman M.S, and Lamb, J.,1990. Osmotic dehydration of pineapple. J. of Food Sci. Technol.27: 150-152.

Sereno, A.M., Moreira, R. \& Martinez, E. 2001. Mass transfer coefficients during osmotic dehydration of apple in single and combined aqueous solutions of sugar and salt. $J$. of Food Engg, 47: 43-49.

Torrengiani, D. 1993. Osmotic dehydration in fruits and vegetable processing. Food Research Int., 26: 59-68.
Torringa, E., E., Esveld, I., Scheewe, R. V. D., Berg, and P.,Bartels. 2001. Osmotic dehydration as a pre-treatment before combined microwave-hot-air drying of mushrooms. J. of Food Engg, 49: 185-191.

Tortoe ,Ch. 2010. A review of osmodehydration for food industry," African J. of Food Sci., 4(6): 303-324.

Uddin M. N., Yesmin S., Khan M. A., Tania M., Moonmoon M., and Ahmed S. 2011. Production of Oyster Mushrooms in Different Seasonal Conditions of Bangladesh. J. Sci. Res. 3 (1): 161-167.

Vaz, J.A., Heleno, S.A., Martins, A., Almeida, G.M., Vasconcelos, M.H. and Ferreira, I.C.F.R. 2010. Wild mushrooms Clitocybe alexandri and Lepista inversa: In vitro antioxidant activity and growth inhibition of human tumour cell lines. Food and Chem. Toxicology 48: 2881- 2884. 